\title{
On the GBS Bernstein-Stancu's type operators
}

\section{DAN MiclăUŞ}

\section{ABSTRACT.}

In the present paper we establish the form of remainder term associated to the GBS (Generalized Boolean Sum) Bernstein-Stancu's type operators, using bivariate divided differences.

Acknowledgement. I thank the reviewer for his suggestions leading to the improvement of the first version of this paper.

\section{REFERENCES}

[1] Abel, U. and Ivan, M., New representation of the remainder in the Bernstein approximation, J. Math. Anal. Appl., 381 (2011), No. 2, $952-956$

[2] Bărbosu, D., Two dimensional divided differences revisited, Creat. Math. Inform., 17 (2008), No. 1, 1-7

[3] Bărbosu, D. and Pop, O. T., A note on the GBS Bernstein's approximation formula, An. Univ. Craiova, Math. Comp. Sci. Ser., 35 (2008), 1-6

[4] Bernstein, S. N., Démonstration du théorème de Weierstrass fondée sur le calcul de probabilités, Commun. Soc. Math. Kharkow, 13 (1912-1913), No. $2,1-2$

[5] Della Vecchia, B., On the approximation of functions by means of the operators of D. D. Stancu, Studia Univ. Babeş-Bolyai, Mathematica, 37 (1992), No. 1, 3-36

[6] Delvos, F. J. and Schempp, W., Boolean Methods in Interpolation and Approximation, Pitman Research Notes in Mathematics Series 230, Longman Scientific \& Technical, New York, 1989

[7] Gordon, W. J., Distributive lattices and the approximation of multivariate functions, in Proceedings of the Symposium on Approximation with Special Emphasis on Splines, New York, (Schoenberg, I. J., Ed.), Acad. Press, 1969, 223-277

[8] Ionescu, D. V., Divided differences (in Romanian), Ed. Acad. R. S. R., Bucureşti, 1978

[9] Ivan, M., Elements of Interpolation Theory, Mediamira Science Publisher, Cluj-Napoca, 2004

[10] Lupaş, L. and Lupaş, A., Polynomials of binomial type and approximation operators, Studia Univ. Babeş-Bolyai, Mathematica, 32 (1987), No. 4 , 61-69

[11] Miclăuş, D., The revision of some results for Bernstein-Stancu type operators, Carpathian J. Math., 28 (2012), No. 2, 289-300

[12] Popoviciu, T., Sur quelques propriétés des fonctions d'une ou de deux variables réeles, Mathematica, (1934), 1-85

[13] Stancu, D. D., Approximation of functions by a new class of linear polynomial operators, Rev. Roum. Math. Pures et Appl., 13 (1968), 1173-1194

[14] Stancu, D. D., On the remainder of approximation of functions by means of a parameter-dependent linear polynomial operator, Studia Univ. BabeşBolyai, Ser. Math.-Mech., 16 (1971), 59-66

DePARTMENT OF MATHEMATICS AND COMPUTER SCIENCE

Faculty of SCIENCES North University CENTER At Baia Mare

TECHNICAL UNIVERSITY OF CLUJ-NAPOCA

VICTORIEI 76, 430122 BAIA MARE, ROMANIA

E-mail address: danmiclausrz@yahoo.com

Received: 07.12.2011; In revised form: 01.04.2012; Accepted: 13.11.2012

2010 Mathematics Subject Classification. 41A36, 41A80.

Key words and phrases. Bernstein operator, Bernstein-Stancu operator, GBS operator, divided difference, approximation formula, remainder term. 